\title{
AN UPDATE ON NATURE SASKATCHEWAN'S HABITAT STEWARDSHIP PROGRAM WORK
}

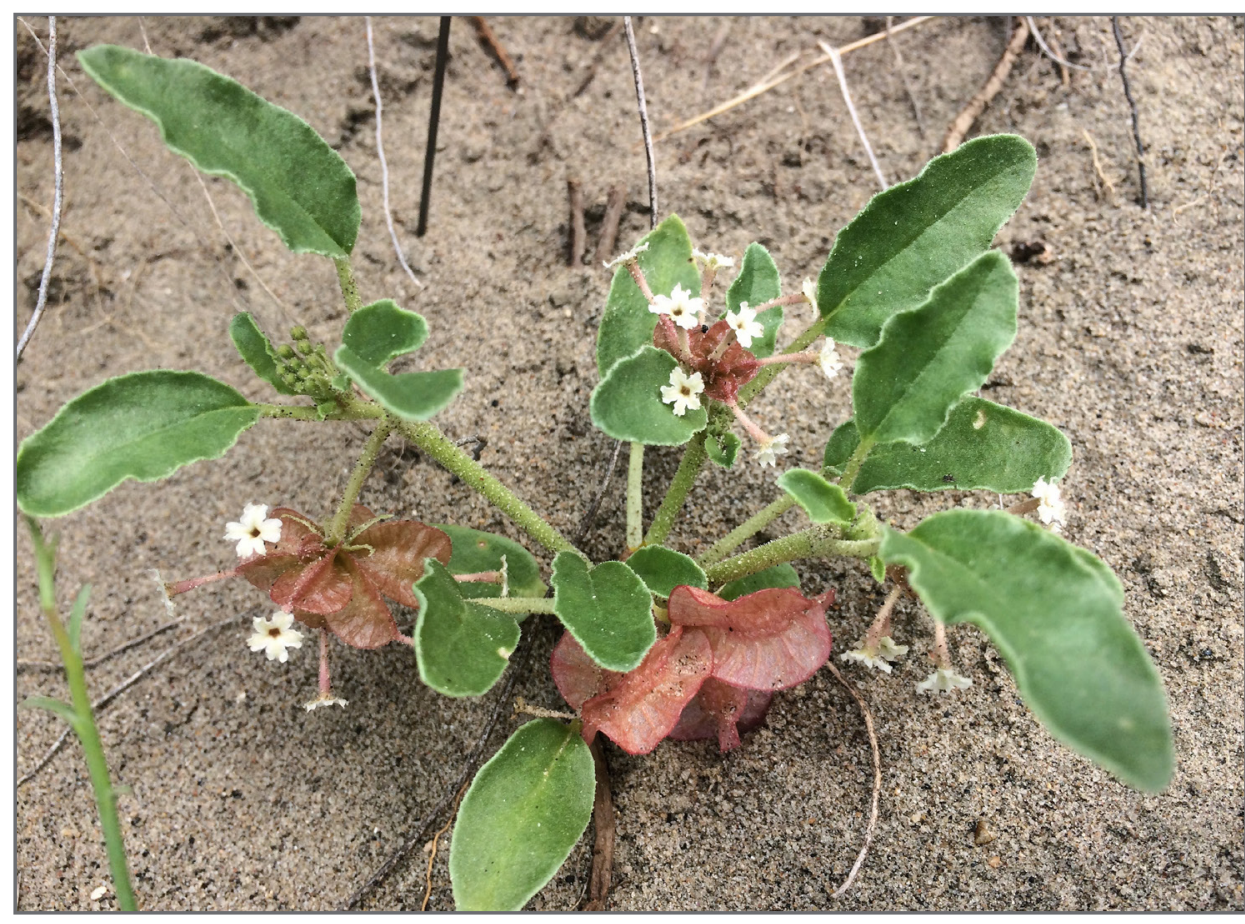

FIGURE 1. Small-flowered Sand-verbena. Photo credit: Emily Putz.

Shirley Bartz, Emily Putz,

Kaytlyn Burrows, Melissa Ranalli

206-1860 Lorne Street

Regina, SK S4P 2L7

mranalli@naturesask.ca

The prairie region is one of the most endangered landscapes in North America; specifically, only 13.7-15 per cent of grassland is thought to remain in Saskatchewan. ${ }^{1}$ Active stewardship by landowners is integral to the conservation of this remaining grassland and the biodiversity it supports, since approximately 85 per cent of southern Saskatchewan's grasslands are privately managed. ${ }^{2}$

Nature Saskatchewan delivers one-of-a-kind voluntary stewardship programs that engage landowners and land managers in species at risk habitat conservation. Species at risk serve to promote awareness of native grassland ecosystems and potential threats to plants and animals living there. The main goals of the programs are to conserve habitat, raise awareness, and provide support to agricultural producers.

Our suite of five stewardship

- Operation Burrowing Owl for the endangered Burrowing Owl (Athene cunicularia);

- Shrubs for Shrikes for the threatened Loggerhead Shrike (Lanius ludovicianus excubitorides);

- Plovers on Shore for the endangered Piping Plover (Charadrius melodus circumcinctus);

- Rare Plant Rescue for 16 species of federally listed and provincially rare plant species; and

- Stewards of Saskatchewan banner program for federally listed and provincially rare species not targeted by one of our other programs.

While our focus is on species targeted by each program, stewardship activities ultimately benefit many other prairie species programs, include:

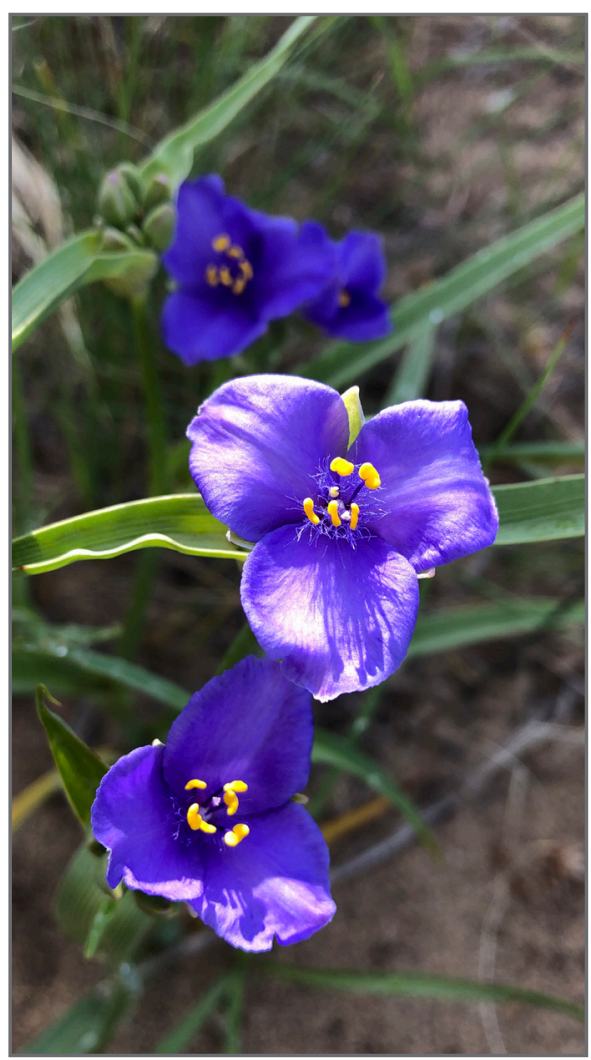

FIGURE 2. Western Spiderwort. Photo credit: Emily Putz.

and their habitats.

The stewardship programs encourage conservation and enhancement of habitat by educating landowners, encouraging informed stewardship, and building relationships. Landowners with habitat supporting species at risk are invited to participate by signing a voluntary stewardship agreement explicitly committing to conserve these areas. One way in which we engage rural landowners and land managers is by acknowledging and documenting their unique understanding of wildlife populations living on their land. For example, participants annually report target species at risk presence or absence, reproductive output, as well as any changes to the habitat on their land.

Participants with Burrowing Owl or Sprague's Pipit (Anthus spragueii) habitat are also invited to complete 


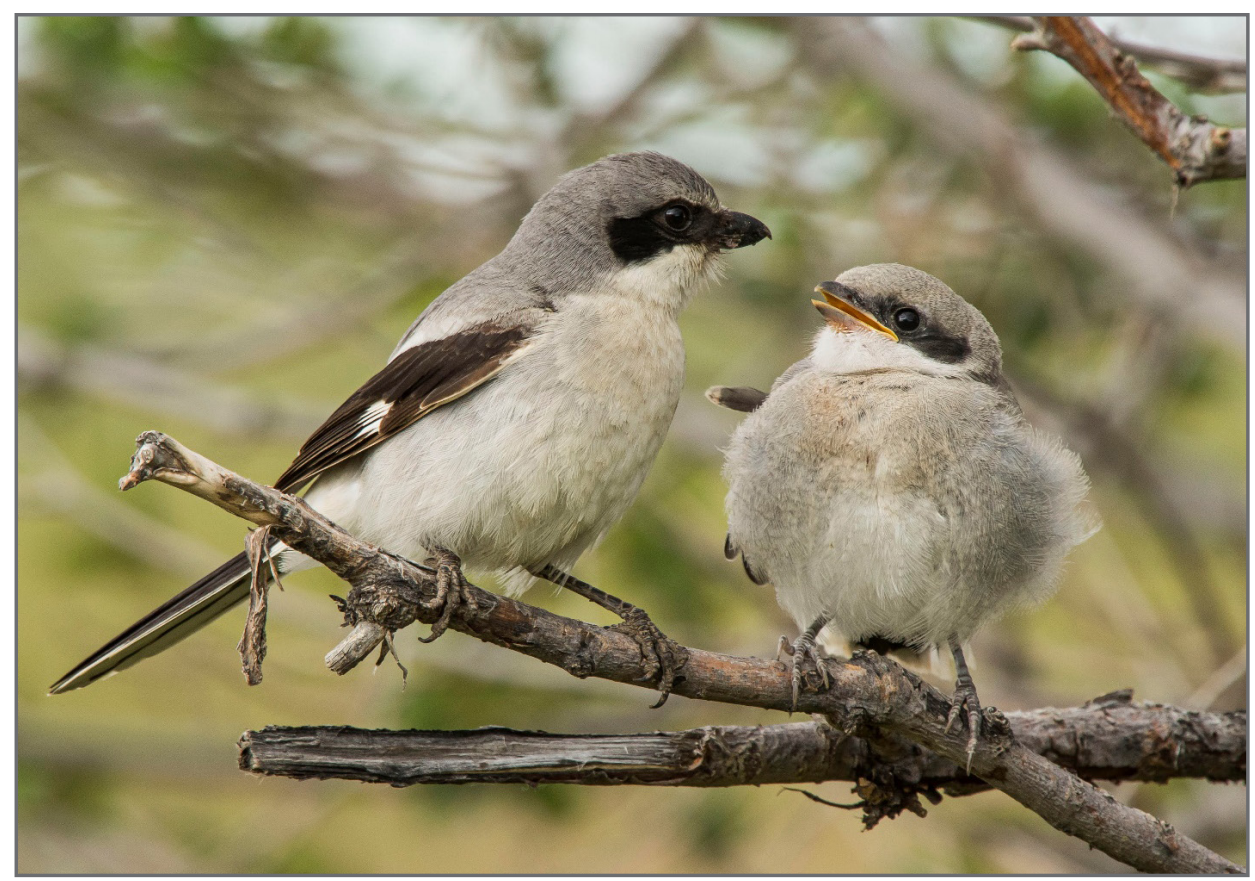

FIGURE 3. Adult Loggerhead Shrike (left) and juvenile shrike (right), Saskatchewan. Photo credit: Boyd Coburn.

a project to enhance this habitat on their land with project costs being shared by Nature Saskatchewan.

Further, participants are encouraged to adopt species at risk beneficial management practices (BMPs) through site-specific plans developed with program coordinators.

Implementation and site-specific adjustments to BMPs are monitored through landowner visits, reported habitat changes, and at the request of the participant.

\section{Rare Plant Rescue Field Work Update}

Launched in 2002, Rare Plant Rescue (RPR) is a stewardship program for landowners with rare plants or habitat where they are likely to occur. Staff conduct targeted surveys on participants' land, and return periodically to monitor the status of any plant species at risk that are found.

During the 2019 field season, RPR staff surveyed 72 quarter sections of land and found more than 1,800 individual plant species at risk (Table 1). Surveys targeted Smallflowered Sand-verbena (Tripterocalyx and Saskatchewan Landing Provincial Park.

Additionally, 18 quarter sections were revisited and past plant species at risk occurrences (individual plants or groups of plants in close proximity) were monitored that have been found in past years. Five of the 18 quarter sections monitored were found to have plant species at risk present; however, Slender Mouseear-cress (Halimolobos virgate) was not detected on the remaining 13 (Table 2). In the process of revisiting known species occurrences, three new occurrences were incidentally detected (i.e., in addition to the occurrences monitored and reported in Table 2); one new occurrence (21 individual plants) of Hairy Prairieclover (Dalea villosa), and two new occurrences of Buffalograss (Bouteloua dactyloides).

RPR staff contacted 40

landowners resulting in 14 visits with current participants, 11 visits with potential participants, and six newly signed RPR participants. In total, 82 RPR participants are conserving 145,262 acres (58,785 hectares) of plant species at risk habitat.

TABLE 1. Plant species at risk detected by Rare Plant Rescue staff during 2019 surveys.

\begin{tabular}{|c|c|c|c|}
\hline SPECIES & $\begin{array}{l}\text { NUMBER OF QUARTER } \\
\text { SECTIONS SURVEYED }\end{array}$ & $\begin{array}{l}\text { NUMBER OF } \\
\text { OCCURRENCES }\end{array}$ & $\begin{array}{l}\text { NUMBER OF } \\
\text { INDIVIDUAL PLANTS }\end{array}$ \\
\hline Small-flowered Sand-verbena & 53 & 5 & 45 \\
\hline Western Spiderwort & $12 *$ & 8 & 1,063 \\
\hline Smooth Goosefoot & $17 *$ & 30 & 443 \\
\hline Tiny Cryptantha & 2 & 0 & 0 \\
\hline Small Lupine & Incidentally located & 36 & 322 \\
\hline
\end{tabular}

*Of these 17 quarter sections surveyed, 12 were concurrently surveyed for Western Spiderwort.

TABLE 2. Plant species at risk located by Rare Plant Rescue staff during 2019 monitoring.

\begin{tabular}{|l|l|l|l|}
\hline \multicolumn{1}{l}{$\begin{array}{l}\text { SPECIES } \\
\text { NEMBER OF QUARTER }\end{array}$} & $\begin{array}{l}\text { NUMBER OF } \\
\text { OCCURRENCES }\end{array}$ & \multicolumn{1}{l|}{$\begin{array}{l}\text { NUMBER OF } \\
\text { INDIVIDUAL PLANTS }\end{array}$} \\
\hline Slender Mouse-ear-cress & 13 & 0 & N/A \\
Western Spiderwort & 1 & $9 *$ & 4,261 \\
\hline Small-flowered Sand-verbena & 1 & 2 & 280 \\
Hairy Prairie-clover & 1 & 2 & 509 \\
Buffalograss & 2 & 22 & N/A \\
\hline
\end{tabular}

*Four occurrences were located on the one quarter section monitored, while the other five were monitored while conducting targeted surveys elsewhere in Douglas Provincial Park. 
TABLE 3. The number of individuals of program target species reported through the 2019 censuses to date.

\begin{tabular}{|c|c|c|c|c|}
\hline PROGRAM & $\begin{array}{l}\text { CENSUS } \\
\text { COMPLETION } \\
\text { STATUS }\end{array}$ & $\begin{array}{l}\text { NUMBER OF } \\
\text { PARTICIPANTS } \\
\text { WHO HAVE } \\
\text { RESPONDED TO } \\
\text { DATE }\end{array}$ & $\begin{array}{l}\text { TARGET } \\
\text { SPECIES } \\
\text { REPORTED }\end{array}$ & $\begin{array}{l}\text { NUMBER OF INDIVIDUALS } \\
\text { REPORTED }\end{array}$ \\
\hline $\begin{array}{l}\text { Operation } \\
\text { Burrowing Owl }\end{array}$ & $51 \%$ & 158 of 309 & $\begin{array}{l}\text { Burrowing } \\
\text { Owl }\end{array}$ & $\begin{array}{l}22 \text { ( } 8 \text { pairs, } 6 \text { singles, and } 0 \\
\text { juveniles) }\end{array}$ \\
\hline $\begin{array}{l}\text { Shrubs for } \\
\text { Shrikes }\end{array}$ & $19 \%$ & 46 of 243 & $\begin{array}{l}\text { Loggerhead } \\
\text { Shrike }\end{array}$ & $\begin{array}{l}59 \text { ( } 21 \text { pairs, } 11 \text { singles, and } 6 \\
\text { juveniles) }\end{array}$ \\
\hline $\begin{array}{l}\text { Plovers on } \\
\text { Shore }\end{array}$ & $16 \%$ & 10 of 61 & Piping Plover & $\begin{array}{l}12 \text { ( } 3 \text { pairs, } 4 \text { singles, and } 2 \\
\text { juveniles) }\end{array}$ \\
\hline \multirow{9}{*}{$\begin{array}{l}\text { Stewards of } \\
\text { Saskatchewan } \\
\text { Banner }\end{array}$} & \multirow[t]{9}{*}{$11 \%$} & \multirow[t]{9}{*}{15 of 142} & \multirow{9}{*}{$\begin{array}{l}\text { Multiple } \\
\text { Species }\end{array}$} & 179 Barn Swallows \\
\hline & & & & 3 Ferruginous Hawks \\
\hline & & & & $\geq 12$ Sprague's Pipits \\
\hline & & & & $\geq 6$ Bobolink \\
\hline & & & & $\geq 6$ Common Nighthawks \\
\hline & & & & 9 American Badgers \\
\hline & & & & $\geq 29$ Northern Leopard Frogs \\
\hline & & & & $\geq 2$ Western Tiger Salamanders \\
\hline & & & & 17 Monarch Butterflies \\
\hline
\end{tabular}

\section{Bird Species at Risk Programs and Stewards of Saskatchewan Banner Program Field Work Update}

Nature Saskatchewan's Operation

Burrowing Owl (OBO) program was launched in 1987 to protect Burrowing Owl habitat from cultivation, monitor population changes, and to increase awareness of the owl. In addition to coordinating the Saskatchewan portion of the International Piping Plover Breeding Census every five years, Nature Saskatchewan initiated Plovers on Shore (POS) in 2008 for landowners that manage lands and habitat for this endangered species. Shrubs for Shrikes (SFS), launched in 2003, focuses on conserving grassland and shrub habitat for the threatened Loggerhead Shrike (Figure 3). Nature Saskatchewan's Stewards of Saskatchewan (SOS) banner program was launched in 2010 to include all prairie species at risk that are not already targeted by our other stewardship programs. For example, landowners supporting habitat for the Sprague's Pipit (Anthus spragueii), Barn Swallow (Hirundo rustica), Ferruginous Hawk
(Buteo regalis), Bobolink (Dolichonyx oryzivorus), Common Nighthawk (Chordeiles minor), American Badger (Taxidea taxus taxus), Northern Leopard Frog (Lithobates pipiens), Western Tiger Salamander (Ambystoma mavortium), or Monarch (Danaus plexippus) are engaged through this program.

Since the beginning of our 2019 field season (including the Ferruginous Hawk work described below), 74 current participants have been visited (4 POS, 16 SOS, 22 SFS and 32 OBO); 115 potential participants have been visited (6 POS, 59 SOS, 35 SFS and 15 OBO); and 75 new participants joined one of our programs (3 POS, 31 SOS, 30 SFS and 11 OBO). Two habitat enhancement projects (with 50 per cent of costs covered by Nature Saskatchewan) have been initiated to improve habitat for the Burrowing Owl, and one for the Piping Plover. Additionally, 45 BMP plans have been distributed to landowners (4 POS, 8 SOS, 19 SFS and 14 OBO). In total, 66 POS, 162 SOS, 270 SFS, and 361 OBO participants are conserving 145 miles (233 kilometers) of shoreline (POS), and 325,505 acres $(131,727$ hectares) of species at risk habitat (SOS, SFS, and OBO).

In 2019, Nature Saskatchewan partnered with the Saskatchewan Conservation Data Centre to contact private landowners who were identified as having Ferruginous Hawks nesting on their property during a survey organized by the Ministry of Environment and Saskatchewan Conservation Data Centre in 2018. From April to May 2019, Nature Saskatchewan staff mailed out 82 letters notifying landowners of Ferruginous Hawk nesting activity on their land, with an additional 20 landowners visited in person during spring field visits. All landowners contacted were invited to participate in our Stewards of Saskatchewan banner program, and six new participants signed on through this specific outreach.

The summer mailout was sent to all program participants on June 7 , 2019 and it included census cards, program updates, a summer/fall events list, and an information sheet on grain bag recycling. The OBO, SFS, POS, and SOS census results continue to be received by program coordinators. Current census data are summarized in Table 3, and a finalized summary of census data is expected to be available on the Stewards of Saskatchewan webpage in December 2019.

\footnotetext{
1. Doke Sawatzky, K. 2018. The Prairie Commons Project: A Reporter's Journey Through Saskatchewan's Grasslands. http://www.prairiecommons.ca. Accessed March 11, 2019.

2. Saskatchewan Watershed Authority. 2002. A Land Manager's Guide to Grassland Birds of Saskatchewan.
} 